\title{
An Analysis of Lexical Negative Transfer in English Writing of Malay Students
}

\author{
Ha Ming Hui \\ Aryantie Ariffin \\ Aini Marina Ma'rof \\ Faculty of Educational Studies \\ Universiti Putra Malaysia \\ Malaysia
}

Email: ainimarina@upm.edu.my

\begin{abstract}
This is an exploratory research examining written work in English of Malay college students, analysing lexical errors that occurred in their work, which were caused by the negative transfer from the students' mother tongue. The study also categorized the errors and gave some pedagogical suggestions on reducing the lexical errors to improve students' English writing. Students involved were Malays at foundation level, with an age range from 17 years to 19 years old. Out of 40 participants, 15 of them were males and 25 were females. The categorical analysis and findings of this study aim to gain educators' understandings on Malay-based lexical negative transfer problems in learning English and trigger educators to take note on the problems in order to improve students' language learning strategy.
\end{abstract}

Keywords: Negative transfer, lexical errors, English writing, Malay students

\section{INTRODUCTION}

Malaysian education places emphasis on the three basic skills of reading, calculating and writing. This would ensure that the students are equipped with the basic skills in pursuit of academic excellence. As all those skills are important, this research scope focused on the writing skill because it is one of the vital skills that all students must master from the earliest age. Students must equip themselves with this essential skill, whether in the Malaysian national language which is the Malay language (Bahasa Malaysia) or in English language. As the majority of students in Malaysia converse in their mother tongue, which is the Malay language, problems occur when they have to complete their task either at school or higher learning institution resulting from their lack of skills in mastering the second language which is English.

From the earliest age, children enrolled in kindergarten have already been exposed to English language with the aim of familiarising these children with the language either in conversing or enhancing their writing ability, so that they will master it when they enrol to higher education institution. Language transfer occurs when the understanding or learning process of a second language is affected by the first language of an individual. Generally, there are two types of language transfer: positive transfer 
and negative transfer. In this research, the main focus is to determine the negative transfer in English writing of Malaysian students ("Language transfer", 2016).

Yet, most of the students have problems in English language because of the interfering process in translation of their mother tongue or first to English which is their second language, in terms of pronunciation, vocabulary and grammar. The process of interpretation between the first language and second language may affect the acquisition of English language when the students negatively transferred their first language into second language which is the English language.

Being a multiracial country, there are many other vernacular languages in Malaysia, but English language holds prominence due to its importance in Malaysia's interaction with the rest of the world. A high proficiency in English language would possibly increase Malaysians' global competency. Therefore it is crucial to improve English proficiency as it is highly important in terms of global competitiveness and nation building. As mentioned above, negative transfer becomes the main obstacle in students' English learning. Thus, the strategy to improve this situation is the major issue according to Arukesamy (2015).

\section{PROBLEM STATEMENT}

Since the 1940s and 1950s, the interest of researchers and linguists is to determine the effects and impacts of the language transfer between first language to second language (Chen and $\mathrm{Li}, 2016$ ). A number of studies have been conducted by linguists and researchers; especially on the negative transfer from the first language to second language (Guo, Liu, and Chen, 2014). Among all the outcomes classified by Odlin (1989), include positive transfer, negative transfer, and differing lengths of acquisition. Odlin (1989) was concerned more on the outcomes of negative transfer (Guo, Liu, \& Chen, 2014). This finding indicates and benchmarks the significance of negative transfer of first language to the second language.

Since our country is multiracial, Malaysian students are proficient in their mother tongue such as Bahasa Malaysia, Tamil, and Mandarin. Based on this, there is a probability that lexical errors in the mother tongue will influence students' performance in writing, speaking and reading in English.

Malay students may have difficulties in structuring sentences in English. For example, they might build English sentences with broken structure as follows:

*I got result exam very good last semester. ${ }^{1}$

*I got a good result for last semester examination.

Moreover, students also tend to directly translate words from Malay to English.

Example: *Ali story the story to his father.

Ali tells the story to his father.

Ali menceritakan cerita itu kepada ayahnya. (Malay sentence) 
These examples show that first language or mother tongue has interfered with students' learning or acquisition of the target language especially in the speaking and writing skills of Malay students.

As mentioned above, recent researches have focused a lot on issues about the negative transfer on second language acquisition, especially Chinese-English negative transfer. However, only a few studies were found concerning Malay-based negative transfer in English. Within the few researches found, through available resources, none of the researches categorized Malay-based negative transfer in English into detailed lexical categories. Thus, this research aims to explore on the lexical transfer errors made by Malay students in English writing hoping to alert researches on this specific issue and to trigger researchers and educators to take note on the problems in their language teaching practice.

\section{RESEARCH QUESTIONS}

i. What lexical negative transfer errors do Malay students make in English writing?

ii. Which is the most common type of lexical negative transfer errors made by Malay students in English writing?

\section{LITERATURE REVIEW}

Malaysia is a multiracial country with each of the individual ethnics practicing their own mother tongue. When these individuals who do not share the same language communicate, language contact occurs. According to Odlin (as cited in Camilleri, 2004, p.11), language contact leads to the emergence of language mixing, new dialects, code switching, transfer and other language varieties.

The speakers possibly take the feature of pronunciation, vocabulary or grammar from their mother tongue language into their second or third language (Trask, 1997). When speakers apply the semantic or syntactic rules of other language to the target language without overtly switching languages, the process is known as language transfer (Odlin, 1989).

If there are mismatches between themselves and the target language, negative transfer will take place and this situation might impede the acquisition of the target language. Hence the learners are prone to producing errors in performing the target language. According to Odlin (1989), errors that are produced due to the negative transfer can be categorized into three types. One may use the mother tongue form into the target language; literal translation and alternation of structure. In addition to producing errors, negative transfer can also cause underproduction in which a language learner produces few or no examples of a target language structure, overproduction, which is a consequence of underproduction and misinterpretation that one may misinterpret the target language messages when applying their first language over the target language messages. 
Generally, most studies conducted to find causes and sources of error analysis generated a conclusion that mother tongue interference is the main factor that is responsible for the cause of errors in students' writings.

Camilleri (2004) pointed out that negative transfer occurs at the sentence level of student's writing in the target language as the students make syntactical and lexical errors such as word order, prepositions, the use of verbs and idioms in the sentences. The sources of error produced by the students are mainly due to the literal translation and L1 form that due to transferring the first language into the target language. The study identifies that every time an error occurs in the students writing, there are mismatches between the L1 and L2 features

\section{METHODOLOGY}

\section{Research Design}

This study is an exploratory research. Data was obtained from marked papers by professional English teachers. All mistakes made by students in the papers were listed down. The correct answers given by English teachers were listed down too. Mistakes were then compared with the corrections. After comparison, researchers analysed on the errors and defined if they were lexical negative transfer errors. The researchers invited a Malay native speaker to discuss with one of our researchers who is also a native speaker of Malay on the identification of lexical negative transfer. Advices from an English teacher and a native speaker of English were adopted as well to gain reliability of identification. In this study, quantitative research is conducted to analyse the errors and qualitative research is employed in the analysis and description of the errors.

\section{Sample and Setting}

This study was conducted in a college located at the centre of Kuala Lumpur. Target students were at foundation level. There were 40 students in total who participated in this research. 15 of them were male students and 25 of them were female students. The participants were college students whose age ranges was from 17 years to 19 years old. All the participants were Malay students with the Malay language as their mother tongue.

\section{Data Collection}

Approval from the college was obtained to conduct the study. Convenience sampling was used in the data collection. Students of recommended lecturers were approached at the classroom. Only students who happened to be in the classroom at the time of data collection were approached. The purpose of the study was explained to the students. Consents were obtained from students who were willing to participate in the study. Their right to withdraw from the study was assured. Besides, anonymity of participants and confidentiality of their information were assured before students participated in the study. Participants' written works in their English class which they have completed for the particular week were collected. These written works included paragraph writings, 
essays and long answers to subjective questions their teachers have assigned. The papers collected are of different types and lengths. Furthermore, the collection number depended on the assignments given by their English teachers. The papers were all marked by their English teachers. To ensure the confidentiality of data, the works collected were coded. All data collected were locked in a cabinet and only the primary researcher has access to it.

\section{DATA ANALYSIS}

The collected papers were examined and students' errors in their written English works were analysed. The lexical errors were then identified if they were the occurrences of negative transfer. All the lexical negative transfer errors were then classified into categories including verbs, adjectives, nouns, pronouns and prepositions.

\section{FINDINGS}

From the essays that were collected from the sample of this research, the results of this study are as below:

Table 1: Number of Mistakes

\begin{tabular}{cc}
\hline Categories & Number of Mistakes \\
\hline Noun & 8 \\
Conjunction & 6 \\
Word Order & 3 \\
Verb & 57 \\
\hline
\end{tabular}




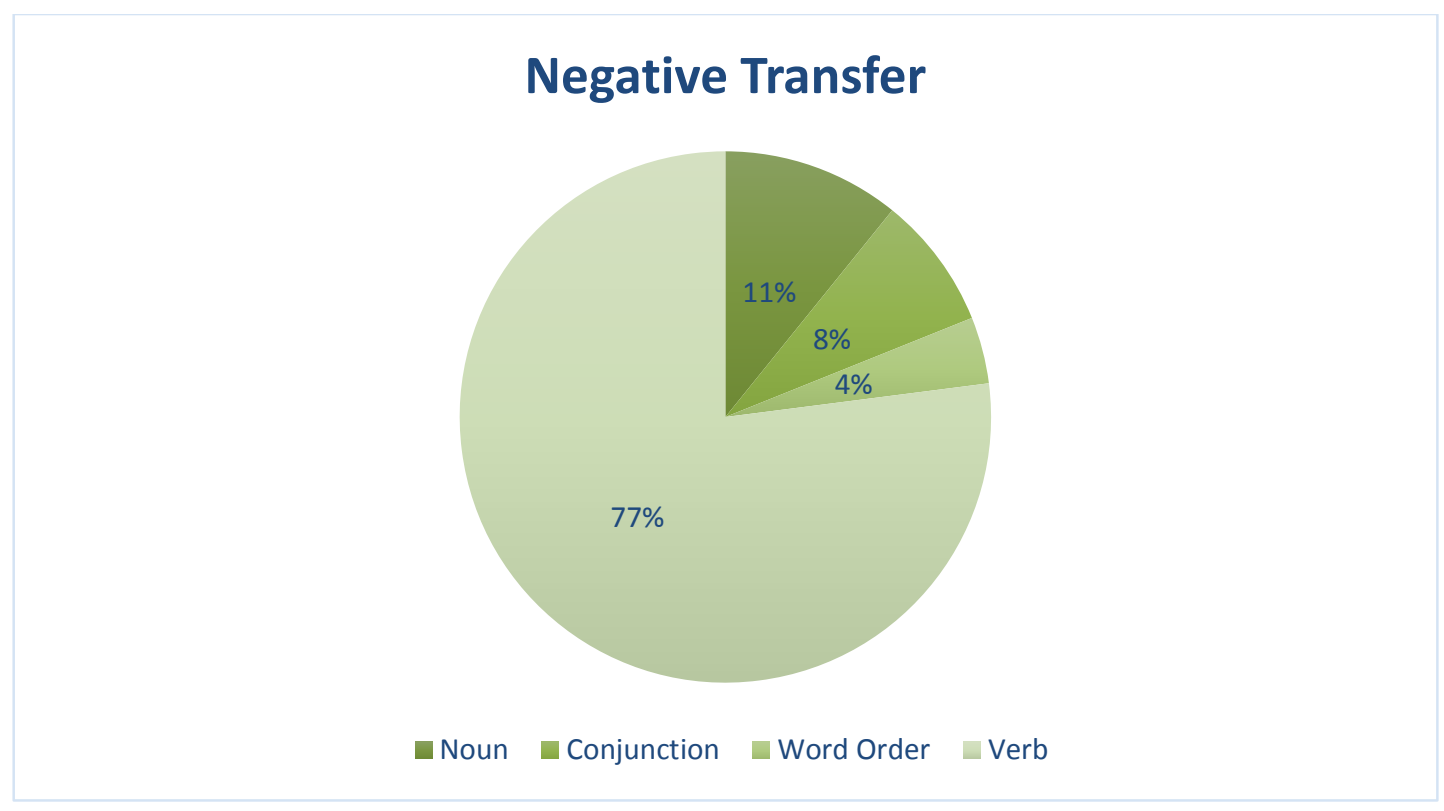

Figure 1: Number of Mistakes

Percentages of the mistakes made are shown in the pie chart above. From Figure 1 , we could see that $4 \%$ mistakes made are in word order form, $8 \%$ of the mistakes are conjunction mistakes, $11 \%$ are nouns and $77 \%$ are verbs. We could see that most of the mistakes made by the Malay students in English is verb, thus we could conclude that the common negative transfer made by Malay students in English is verb.

\section{Noun}

In English, the amount of an object is usually expressed using singular or plural form of nouns. In Malay Language, the amount of an object is expressed by repeating the words. This leads to confusion at the use of singular and plural. For example:

*a mosquito that flys ... (From student's homework)

a mosquito that flies ... (The correct answer)

\section{Conjunction}

Conjunction syntactically links words and larger constituents. There is a misuse of conjunction 'so'. For example:

*We so enjoy the moment what we do in weekend.

(From student's homework)

We enjoyed the moment and what we did during the weekend.

(The correct answer)

The use of 'so' here is a negative transfer from Malay Language word of 'sangat'.

A conjunction which marks a complement clause is called 'complimentizer'. Some examples of complimentizer include 'if', 'that', 'to' etc. Complimentizer is seldom used in Malay, thus, Malay students found it hard to master. For example: 
*We are hoping nothing goes wrong. (From student's homework)

We are hoping that nothing will go wrong. (The correct answer)

\section{Word Order}

Some Malay words are expressed differently from English in the sense of order. Therefore, Malay students always write English phrases with the wrong word order due to the negative transfer. For example:

*You can use the pen I gave you, or you can use the pencil colour. (From student's homework)

You can use the pen I gave you, or you can use the colour pencil. (The correct answer)

In Malay, colour pencil is called 'pensil warna', which is in reverse order of English expression

\section{Verb}

Malay students were found very poor in mastering English verbs. This is because the tense does not exist in Malay. For example:

*has drinked... (From student's homework)

has drunk... (The correct answer)

Another type of problem with verbs was found is the suffix form. For example:

*The children are play a game. (From student's homework)

The children are playing a game. (The correct answer)

Students also make many mistakes in the usage of verbs to express time. For example:

*I have not been to the beach for last summer. (From student's homework)

I have not been to the beach since last summer. (The correct answer)

\section{DISCUSSION}

English proficiency in writing is significantly affected by the native language of the students. During the process transfer of learning in English language, the process can be either positive transfer or negative transfer. There are quite a number of findings which indicate that during the language transfer, negative transfer will take over positive transfer (Johari, 2009). Chomsky's Universal Grammar indicates that the unmarked settings of 'parameters' properties of grammar that generally differ between one language may be transmitted before marked setting. The transferring process will be quite a difficult process since the learner already has a marked setting. Most of the student's errors that occur in the finding are significant impact from the marked setting in Malay language that has been set by the students (Cook \& Newson, 2007). 
The findings from this research provide interpretations of the end product for the students that learn the English language as the second language. This research also demonstrates the extent and effects of the native language interference with the second language which is English language. Students will use their knowledge in their native language to help them in the English writing process that then indicate the direct interference to their second language (Maisarah, 2016).

\section{CONCLUSION AND RECOMMENDATIONS}

The findings of this research enable educators to have a clearer view of lexical transfer errors from Malay to English language. By having knowledge about the problem of transfer, language teaching will be more effective as educators can pinpoint the Malaybased errors. By summarizing the most common type of Malay-based lexical transfer errors, this research hopes to alert educators on the major lexical transfer error, so that educators can emphasize accordingly on the differences between two languages while teaching and enhance students' learning of the target language.

\section{REFERENCES}

Aleeva, D. (2012). Negative transfer in the writing of proficient students of Russian: A comparison of heritage language learners and second language learners (postgraduate). Portland State University.

Arukesamy, K. (2015). Students losing out due to lack of English skill. The Sun Daily. Retrieved from http://www.thesundaily.my/news/1421066

Azirah, H. (1999). Crossliguistic influence in the written English of Malay undergraduates. Journal of Modern Languages, 12(1), 60-76.

Camille, M. (2004). Negative transfer in Maltase students' writing in English. Journal of Maltase Education research, 2(1), 3-12.

Chen, Y., \& Li, X. (2016). Effects of L1 transfer on English writing of Chinese EFL students. Cross-Cultural Communication, 12(4), 50-53.

Cook, V., \& Newson, M. (2007). Chomsky's universal grammar. Malden, MA: Blackwell Pub.

Cormier, S., \& Hagman, J. (1987). Transfer of learning. San Diego: Academic Press.

Guo, M., Liu, J., \& Chen, P. (2014). A case study on the effect of Chinese negative transfer on English writing. TPLS, 4(9), 1941-1947.

Johari, A. (2009). Syntactic transfer among form four Malay students. Kota Samarahan: Universiti Malaysia Sarawak.

Language transfer. (2016). En.wikipedia.org. Retrieved 4 November 2016, from https://en.wikipedia.org/wiki/Language_transfer\#Positive_and_negative_transfer

Maisarah. (2016). Common grammartical errors made by beginner level students (A study of language interference) (1st ed.). Retrieved from http://download.portalgaruda.org/article.php?article $=116426 \& v a l=5320$

Odlin, T. (1989). Language transfer: Cross-linguistic influence in language learning. Cambridge: Cambridge University Press.

Task, R. (2001). Mind the gaffe ( $1^{\text {st }}$ ed.). London: Penguin Books.

Yong, Y. M., \& Lee, C. K. (2015). Types of Linguistic Error on Mandarin Time Phrase Constructionamong Malay Learners. International Journal of Language Education and Applied Linguistics (IJLEAL), 2, 3-15. 


\begin{abstract}
AUTHORS
Ha Ming Hui is currently a graduating Masters student of Educational Psychology at Universiti Putra Malaysia. She is also a part time lecturer at New Era University College. She teaches and conducts research in the area of second language teaching and learning. She holds a bachelor's degree in Teaching Chinese as a second language from East China Normal University at Shanghai, China.

Aryantie Ariffin is currently an Assistant Director in Institut Kajian dan Latihan Integrasi Nasional, Department of Unity. She coordinates training for government staff and also members in Rukun Tetangga in the area of Mediation. She received her Master of Education in Educational Psychology from Universiti Putra Malaysia. She also holds a bachelor's degree in Construction Management from Universiti Teknologi Mara.

Aini Marina Ma'rof is currently a senior lecturer in Educational Psychology affiliated with Universiti Putra Malaysia. She teaches and conducts research in the area of cognitive sciences of teaching and learning. She received her postgraduate training from the University of Illinois at Urbana-Champaign, USA and was a research member of its Center for the Study of Reading. She also holds a bachelor's degree in Teaching English as a second language, minoring in Teaching Literature in English.
\end{abstract}

